\title{
Effects of oestrogen deprivation on interleukin-6 production by peripheral blood mononuclear cells of postmenopausal women
}

\author{
D Rachoń, J Myśliwska, K Suchecka-Rachoń ${ }^{1}$, J Więckiewicz \\ and A Myśliwski \\ Department of Histology and Immunology of the Medical University of Gdańsk, 80210 Gdańsk, ul. Dębinki 1, Poland \\ ${ }^{1}$ Department of Hypertension and Diabetology of the Medical University of Gdańsk, 80211 Gdańsk, ul. Dębinki 7, Poland \\ (Requests for offprints should be addressed to D Rachoń; Email: drachon@amedec.amg.gda.pl)
}

\begin{abstract}
Various hormones can influence the expression of interleukin-6 (IL-6) and oestrogens are the most extensively studied. There is, however, controversy about the nature of the IL-6 secreted by human cells and its regulation by $17 \beta$-oestradiol. The aim of this work was to clarify whether oestrogen deprivation after menopause may contribute to an enhanced IL-6 production by peripheral blood mononuclear cells (PBMC) in postmenopausal women. Twenty-two healthy postmenopausal women, age range 45-63 years, with clinical symptoms of oestrogen deficiency were enrolled in the study. The control group consisted of 16 healthy young women, age range 22-31 years, with regular menses and who were not taking oral contraceptives. Levels of IL-6 in the sera and PBMC culture supernatants were measured by the biological B9 cell-proliferation assay and expression of the IL-6 gene in non-stimulated PBMC was detected by RT-PCR. The effect of $17 \beta$-oestradiol on spontaneous IL-6 production by the PBMC of postmenopausal women was also studied in vitro and in vivo. Seventeen out of the twenty-two postmenopausal women were given hormonal replacement therapy of $50 \mu \mathrm{g} 17 \beta$-oestradiol/day transdermally and the spontaneous production of IL-6 by the PBMC was analysed after 6 and 12 months of treatment.

The postmenopausal women had significantly higher serum levels of IL-6 than the young controls. The
\end{abstract}

spontaneous production of IL-6 by non-stimulated PBMC into the culture supernatants was also significantly higher in the postmenopausal women compared with the young. We also found that IL-6 gene expression was present in the non-stimulated PBMC isolated directly from the venous blood of the majority of the postmenopausal women. Women with IL-6 gene expression in the nonstimulated PBMC had significantly lower serum levels of $17 \beta$-oestradiol compared with those where the IL- 6 gene was not expressed in the PBMC. Our in vitro experiments showed that $17 \beta$-oestradiol at concentrations of $10^{-9} \mathrm{M}$ and $10^{-10} \mathrm{M}$ decreased spontaneous IL- 6 production by the PBMC of postmenopausal women. In vivo treatment with $17 \beta$-oestradiol transdermally also significantly decreased spontaneous IL-6 production by the PBMC of postmenopausal women after 12 months of the therapy.

Our results indicate that oestrogen deprivation after menopause may enhance IL-6 production by the PBMC of postmenopausal women. We suspect that the late complications of oestrogen deficiency, such as osteoporosis, coronary heart disease and Alzheimer's disease, may be mediated by an exaggerated production of IL-6 a cytokine which seems to play a pivotal role in the pathogenesis of these age-related diseases.

Journal of Endocrinology (2002) 172, 387-395

\section{Introduction}

Interleukin-6 (IL-6) is a pleiotropic cytokine produced by immune and non-immune cells and organs. Unlike other cytokines, IL-6 is unusual in that its major effects take place at sites distinct from its origin and are consequent upon its circulating concentrations. For this reason, it is called the endocrine cytokine (Papanicolaou \& Vgontzas 2000). Inappropriate expression and production of IL-6 is thought to be involved in the pathogenesis of numerous diseases, including osteoporosis (Manolagas \& Jilka 1995),

coronary heart disease (CHD) (Huber et al. 1999) and Alzheimer's disease (AD) (Mrak et al. 1995). Conversely, these disorders belong to the late complications of menopause and oestrogen replacement therapy may improve them (Lindsay et al. 1984, Stampfer \& Colditz 1991, Tang et al. 1996).

There is, however, controversy about the nature of the IL-6 secreted by human cells and its regulation by oestrogens. Girasole et al. (1992) demonstrated that $17 \beta$-oestradiol inhibits IL-6 production in several types of osteoblastic cells in vitro including murine stromal 
cell lines, murine osteoblasts and human osteoblasts. In addition, oestrogens have been shown to inhibit IL-1 $\beta$ - and tumour necrosis factor (TNF $\alpha)-\alpha$-stimulated IL-6 secretion by the human fetal osteoblast cell line (hFOB/ER9) which expresses a high level of oestrogen receptors (Kassem et al. 1996a). Conversely, oestrogen loss results in increased IL-6 production by ex vivo bone marrow cell cultures (Passeri et al. 1993), and increased IL-6 production follows withdrawal of $17 \beta$-oestradiol from primary cultures of calvarial cells (Passeri et al. 1994). In vivo studies also showed that women taking hormone replacement therapy (HRT) have significantly lower serum IL-6 levels compared with subjects not taking HRT (Straub et al. 2000).

In contrast, subsequent studies by three groups (Chaudhary et al. 1992, Rickard et al. 1992, Rifas et al. 1995) could not demonstrate a regulatory effect of ovarian steroids on IL-6 secretion in animal and human bone cell systems. In addition, McKane et al. (1994) did not find any differences in serum IL-6 levels when comparing pre- and postmenopausal women, and there was no difference in IL-6 levels in bone marrow aspirates from postmenopausal women with or without HRT (Kassem et al. 1996b).

In view of these contradictory findings obtained in different cell models, the present study was carried out to clarify whether oestrogen deprivation and HRT have an effect on the production of IL-6 by the peripheral blood mononuclear cells (PBMC) of postmenopausal women.

We have compared serum levels of bioactive IL-6 as well as spontaneous IL-6 production into the supernatants by non-stimulated PBMC in young and postmenopausal women. We have also studied expression of the IL-6 gene in non-stimulated, freshly isolated PBMC of both groups. The in vitro and in vivo effects of $17 \beta$-oestradiol on spontaneous IL-6 production by the PBMC of postmenopausal women were also studied.

\section{Materials and Methods}

\section{Subjects and study design}

Twenty-two healthy postmenopausal women, age range 45-63 years, from the Endocrinological Outpatient Clinic of the Medical University of Gdansk were enrolled in the study. Postmenopausal status was defined as an absence of menstrual periods for at least the previous 6 months and the presence of the oestrogen deficiency symptoms ('hot flushes', increased sweating, nervousness, irritability, depression, palpitations, insomnia, headaches, dyspareunia and joint pains). Four women had experienced surgical menopause. The time since menopause ranged from 6 months to 13 years. The cessation of ovarian function was confirmed by the measurement of serum folliclestimulating hormone (FSH) levels which were all above 40 IU/1. The control group consisted of 16 healthy young women, age range 22-31 years, with regular menses and who were not taking oral contraceptives.

All participants underwent a routine physical examination and routine biochemical screening, including complete blood cell count and chemical group typing. Women from both groups were clinically healthy and were not taking any medication known to affect immunological status, and in the last 2 weeks had had no apparent acute or chronic inflammatory diseases that could result in the elevation of IL-6 levels. Moreover, we selected only those postmenopausal women who were free from osteoporosis (on the basis of bone mass density measurements by X-ray absorptiometry), CHD (on the basis of electrocardiography, biochemical screening and clinical status) and signs of dementia.

All subjects were informed about the purpose of the study and gave written consent. After a detailed talk with the endocrinologist (K Suchecka-Rachon) about the benefits and risks of HRT, 17 out of 22 postmenopausal women were treated with $50 \mu \mathrm{g} 17 \beta$-oestradiol/day transdermally (Estraderm 50MX; Novartis PharmaAG, Basel, Switzerland). Women with an intact uterus (13 subjects) were also receiving $10 \mathrm{mg}$ medroxyprogesterone acetate (Provera; Pharmacia and Upjohn, Ascoli Piceno, Italy) for 10 days during each cycle. Venous blood was taken at baseline and after 6 and 12 months of HRT when patients were not taking the medroxyprogesterone acetate treatment. Blood from the young subjects was drawn between the 5th and 10th day of their menstrual cycle. These studies were approved by the Ethic Committee of the Medical University of Gdańsk.

\section{Sera}

Venous blood was drawn between 0900 and $1000 \mathrm{~h}$ and serum was immediately stored at $-80{ }^{\circ} \mathrm{C}$, in suitably sized aliquots, until thawed for analysis.

\section{Isolation of PBMC}

For cell culture and RNA isolation, blood was drawn on EDTA. Then the PBMC were isolated by centrifugation (2500 r.p.m. for $15 \mathrm{~min}$ at $20^{\circ} \mathrm{C}$ ) using Ficoll-Paque PLUS (Amersham Pharmacia Biotech AB, Uppsala, Sweden). The interphase containing the PBMC was collected and washed twice $(1500$ r.p.m. for $7 \mathrm{~min}$ at $20^{\circ} \mathrm{C}$ ) in phosphate-buffered saline (Gibco BRL, Life Technologies, Berlin, Germany).

\section{PBMC cell cultures}

Non-stimulated PBMC were incubated in RPMI 1640 (Gibco BRL, Life Technologies) supplemented with 5\% heat-inactivated fetal calf serum (FCS) (Gibco BRL, Life Technologies) at about $1 \times 10^{6}$ cells $/ \mathrm{ml}$ on a 24 -well plate (Nunc A/S, Roskilde, Denmark). After 24 h of incubation 
in a humidified atmosphere containing $5 \% \mathrm{CO}_{2}$ at $37^{\circ} \mathrm{C}$, the supernatants were collected and stored at $-80{ }^{\circ} \mathrm{C}$ in aliquots until thawed for analysis.

PMBC of postmenopausal women were also incubated with different concentrations of $17 \beta$-oestradiol (Sigma, Steinheim, Germany). 17 $\beta$-Oestradiol was dissolved in absolute ethanol and prepared as a stock solution of $10^{-4} \mathrm{M}$. The cells were plated in RPMI 1640 supplemented with 5\% heat-inactivated FCS at about $1 \times 10^{6}$ cells $/ \mathrm{ml}$ on a $24-w e l l$ plate. The hormone stock solution was diluted serially in RPMI 1640 before addition to the cells, and added to culture medium to yield $10^{-8}$ to $10^{-11} \mathrm{M}$. Ethanol at a 1:1000 dilution was used as the vehicle control. After $24 \mathrm{~h}$ of incubation in a humidified atmosphere containing $5 \% \mathrm{CO}_{2}$ at $37^{\circ} \mathrm{C}$, the supernatants were collected and stored at $-80^{\circ} \mathrm{C}$ in aliquots until thawed for analysis.

\section{Biochemical assays}

Serum FSH and $17 \beta$-oestradiol measurements were carried out in a diagnostic laboratory using the commercially available Abbott AxSYM assay (Abbott Park, IL, USA) based on microparticle enzyme immunoassay technology.

\section{Isolation of RNA}

After isolating the PBMC from the whole blood, total RNA was extracted with Trizol Reagent (Gibco BRL, Life Technologies Inc., Frederick, MD, USA) according to the manufacturer's instructions. The quantity and quality of RNA were tested spectrophotometrically using $\mathrm{A}_{260} / \mathrm{A}_{280}$ on the UV/VIS Spectrometer MBA 2000 (Perkin Elmer, Norwalk, CT, USA). Additionally, RNA samples were stained with ethidium bromide and ribosomal RNAs (28s and 18s) were visualized on a 1\% agarose gel (Promega, Madison, WI, USA) by the UV transillumination technique (UVP, Upland, CA, USA). Nondegraded RNA was selected for further processing.

\section{RT-PCR}

cDNA was synthesized from $1 \mu \mathrm{g}$ total RNA in a $20 \mu \mathrm{l}$ reaction mixture containing $5 \mu \mathrm{l} 5 \times$ reverse transcription buffer which contained $15 \mathrm{mM} \mathrm{MgCl}, 1.25 \mu \mathrm{l} 10 \mathrm{mM}$ dNTP mixture, $0.5 \mu \mathrm{l}$ ribonuclease inhibitor RNasin, $200 \mathrm{U}$ M-MLV reverse transcriptase and $1 \mu \mathrm{l}$ random primers. All reagents were purchased from Promega. This solution was incubated in a TGradient Thermocycler Modul 96 (Biometra GmbH, Göttingen, Germany) at $42{ }^{\circ} \mathrm{C}$ for $60 \mathrm{~min}$ and then heated at $99^{\circ} \mathrm{C}$ for $5 \mathrm{~min}$.

Aliquots of $3 \mu$ of the total cDNA were amplified in a 33 cycle PCR in a $50 \mu \mathrm{l}$ reaction mixture containing $5 \mu \mathrm{l}$ $10 \times$ PCR buffer which contained $15 \mathrm{mM} \mathrm{MgCl}_{2}$, $38 \cdot 2 \mu \mathrm{l}$ sterile $\mathrm{H}_{2} \mathrm{O}, 1 \mu \mathrm{l}$ dNPT mixture (all from Promega), $1 \mu \mathrm{l}$ IL-6 5'-primer, $1 \mu \mathrm{l}$ IL-6 3 '-primer
(Clontech Laboratories, Palo Alto, CA, USA) and 1.5 U $(0.75 \mu \mathrm{l})$ DyNAzyme II DNA polymerase (Finnzymes, Espoo, Finland). The primers used for PCR were as follows: 5'-primer ATG AAC TCC TTC TCC ACA AGC GC; 3'-primer G AAG AGC CCT CAG GCT GGA CTG. IL-6 cDNA which was provided with the primers by the manufacturer was used as a positive control, and sterile $\mathrm{H}_{2} \mathrm{O}$ as a negative control in the test. In all the RT-PCR experiments, controls for RNA integrity and the proper course of the $\mathrm{RT}$ reaction consisted of parallel cDNA samples run with $\beta$-actin primers. PCR amplification was carried out in a TGradient Thermocycler Modul 96 begining at $95^{\circ} \mathrm{C}$ for $5 \mathrm{~min}$, then $30 \mathrm{~s}$ at $95^{\circ} \mathrm{C}$, $45 \mathrm{~s}$ at $55^{\circ} \mathrm{C}, 1 \mathrm{~min}$ at $72^{\circ} \mathrm{C}$ for 33 cycles and $7 \mathrm{~min}$ at $72{ }^{\circ} \mathrm{C}$. The products of the reaction were cooled to $4{ }^{\circ} \mathrm{C}$, stained with ethidium bromide, sized in a $2 \%$ agarose gel (Promega) and visualized on a transilluminator (UVP, Germany). Gels were photographed using a polaroid system and processed by the program Grab-It (UVP, Upland, USA).

\section{IL-6 bioassay}

IL-6 levels in the sera and in the PBMC culture supernatants were determined using the B9 hybrydoma proliferation assay (Aarden et al. 1987). In this assay, $10 \times 10^{3} \mathrm{~B} 9$ cells (a gift from L Aarden, Netherland Red Cross, Amsterdam, The Netherlands) were cultured on a 96-well plate with 50 times diluted samples of sera or supernatants in a final volume of $100 \mu \mathrm{l}$ RPMI 1640, supplemented with $5 \times 10^{-5}$ M 2-mercaptoethanol (Sigma), 10\% FCS, $100 \mathrm{U} / \mathrm{ml}$ penicillin and $100 \mu \mathrm{g} / \mathrm{ml}$ streptomycin (Sigma). All samples were put onto a 96-well plate in triplicate. After $48 \mathrm{~h}$ of incubation in a humidified atmosphere containing $5 \% \quad \mathrm{CO}_{2}$ at $37^{\circ} \mathrm{C}, \quad 20 \mu \mathrm{l} \quad(3-[4,5-$ Dimethylthiazol-2-yl]-2,5)-diphenyltetrazolium bromide (MTT) (Sigma) was added to each well of the plate. The plate was incubated for the next $4 \mathrm{~h}$ in the above conditions and after this time $100 \mu \mathrm{l}$ isopropanol (Sigma) was added. Optical density was read at $570 \mathrm{~nm}$ on an automated plate reader (Bio-Tek FL600; Bio-Tek Instruments Inc., Winooski, VT, USA). A standard curve relating cell proliferation to doses of recombinant human IL-6 (Sigma) was used to quantify IL-6 activity in the samples.

To confirm the specificity of the test, the monoclonal anti-IL-6 antibody (Genzyme, Rüsselsheim, Germany) was added $(1: 10,1: 20,1: 50)$ to the samples. The anti-IL-6 monoclonal antibody completely inhibited the ability of the $\mathrm{B} 9$ cells to proliferate. This assay has a detection limit of $1 \mathrm{pg} / \mathrm{ml}$. The intra-assay coefficient of variation ranged between 9.5 and $10.9 \%$ and the interassay coefficient of variation between $17 \cdot 7$ and $25 \%$.

\section{Statistical analysis}

All data are presented as arithmetic means \pm S.D. The differences between age groups were evaluated using 
Table 1 Characteristics of the subjects studied

\begin{tabular}{|c|c|c|}
\hline & Postmenopausal women & Young women \\
\hline No. of subjects & 22 & 16 \\
\hline Age (years) & $52 \cdot 77 \pm 4 \cdot 59^{*}$ & $26 \pm 3 \cdot 09$ \\
\hline Years since menopause & $4 \cdot 48 \pm 4 \cdot 26$ & - \\
\hline Serum FSH levels (IU/I) & $68 \cdot 23 \pm 21 \cdot 17^{*}$ & $17 \cdot 63 \pm 8 \cdot 25$ \\
\hline Serum $17 \beta$-estradiol levels (pmol/l) & $85 \cdot 66 \pm 76 \cdot 33^{*}$ & $259 \cdot 77 \pm 132 \cdot 89$ \\
\hline
\end{tabular}

${ }^{*} P<0 \cdot 05$.

Student's unpaired $t$-test. Student's paired $t$-test was used to compare the in vitro as well as the in vivo $17 \beta$-oestradiolinduced effects on the spontaneous IL-6 production by the PBMC of postmenopausal women. $P$ values $<0 \cdot 05$ were considered statistically significant. All analyses were performed using a computer program STATISTICA Edition '99 for Windows.

\section{Results}

\section{Clinical characteristics of the subjects studied}

All participants underwent a routine physical examination and biochemical screening which did not reveal any abnormalities. The characteristics of the two groups studied are shown in Table 1.

As shown in Table 1, the postmenopausal women had significantly lower levels of serum $17 \beta$-oestradiol $(85.66 \pm 76.33 \mathrm{pmol} / 1 \quad$ vs $259 \cdot 77 \pm 132.89 \mathrm{pmol} / 1$, $P<0.05)$ and significantly higher serum levels of FSH $(68 \cdot 23 \pm 21 \cdot 17 \mathrm{IU} / 1$ vs $17 \cdot 63 \pm 8 \cdot 25 \mathrm{IU} / 1, P<0 \cdot 05)$ compared with the young control group. These differences confirmed the state of oestrogen deficiency in the postmenopausal women.

\section{Serum levels of IL-6 in postmenopausal and young women}

In order to find the differences between the levels of IL-6 in the sera of the postmenopausal and young women, the bioactive IL-6 was detected using the B9 cell-proliferation assay. It appeared that the mean serum levels of IL-6 in the postmenopausal women was significantly higher compared with the young women $(4 \cdot 44 \pm 2 \cdot 10 \mathrm{pg} / \mathrm{ml}$ vs $1 \cdot 76 \pm 1 \cdot 38 \mathrm{pg} / \mathrm{ml}, P<0 \cdot 05)$ (Fig. 1).

Spontaneous IL-6 production by the PBMC of postmenopausal and young women into the culture media

In the next experiment, the levels of bioactive IL-6 were compared in the supernatants from the cultures of the non-stimulated PBMC of the postmenopausal and young women. Non-stimulated PBMC from both groups were incubated in a medium supplemented with FCS in a humidified atmosphere with $5 \% \mathrm{CO}_{2}$ for $24 \mathrm{~h}$. After the incubation period, the levels of IL-6 were measured in the supernatants. The results of this experiment revealed that the cultured, non-stimulated PBMC from the postmenopausal women released significantly higher amounts of bioactive IL- 6 into the culture media than those of the young $(13 \cdot 25 \pm 9 \cdot 01 \mathrm{pg} / \mathrm{ml}$ vs $6 \cdot 3 \pm 4 \cdot 23 \mathrm{pg} / \mathrm{ml}$, $P<0 \cdot 05$ ) (Fig. 2).

IL-6 gene expression in the non-stimulated PBMC of postmenopausal and young women

Increased release of bioactive IL- 6 by the non-stimulated PBMC of the postmenopausal women into the culture supernatants suggested the possibility of an endogenous activation of these cells in vivo. In order to clarify this suggestion, expression of the IL-6 gene in the PBMC, isolated directly from venous blood, was studied using the RT-PCR method. The results revealed that a spontaneous expression of the IL-6 gene was present in the PBMC of 15 out of the 22 postmenopausal women (Fig. 3), and was absent in the PBMC of all the young women (data not shown).

These results confirmed an endogenous activation of the IL-6 gene in the PBMC among the majority of the postmenopausal women studied.

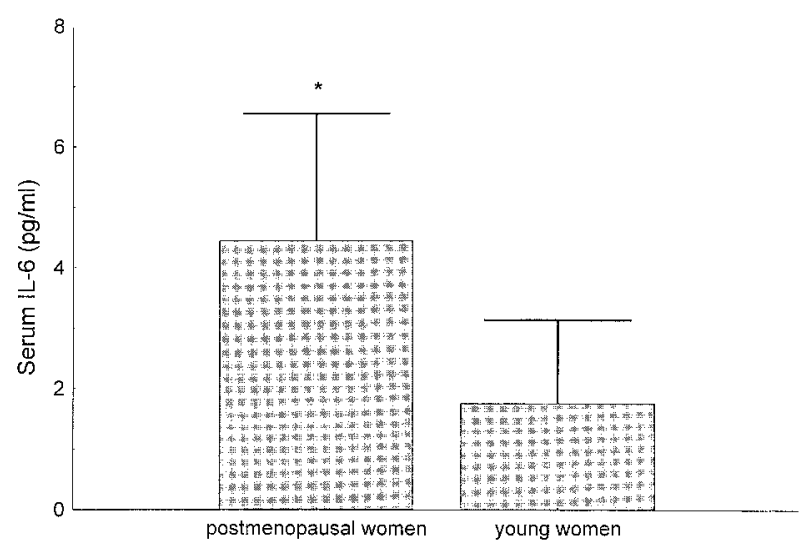

Figure 1 Serum levels of IL- 6 in postmenopausal and young women. The levels of the bioactive IL-6 in the sera were measured using a B9 cell-proliferation assay. The postmenopausal women $(n=22)$ had significantly higher levels of bioactive IL- 6 than the young ones $(n=16)(4 \cdot 44 \pm 2 \cdot 10 \mathrm{pg} / \mathrm{ml} v \mathrm{vs} 1 \cdot 76 \pm 1 \cdot 38 \mathrm{pg} / \mathrm{ml})$ $\left({ }^{*} P<0 \cdot 05\right)$. 


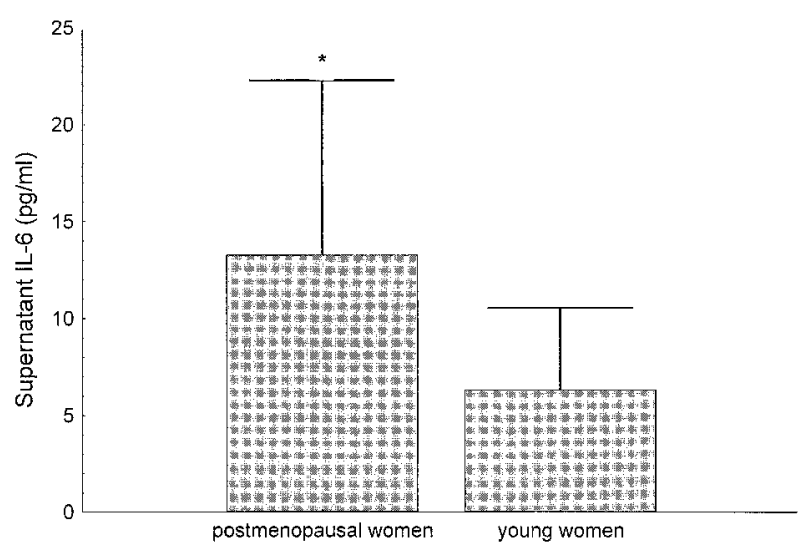

Figure 2 Levels of IL-6 in supernatants from PBMC cultures of postmenopausal and young women. Non-stimulated PBMC from the postmenopausal and young women were incubated in RPMI 1640 , supplemented with $5 \%$ FCS, in a humidified atmosphere with $5 \% \mathrm{CO}_{2}$. After $24 \mathrm{~h}$ of incubation, levels of bioactive IL-6 were measured in the supernatants. Non-stimulated PBMC from the postmenopausal women $(n=22)$ released into the supernatants significantly higher amounts of IL-6 compared with the PBMC of the young women $(n=16)(13 \cdot 25 \pm 9 \cdot 01 \mathrm{pg} / \mathrm{ml} \mathrm{vs}$ $6 \cdot 3 \pm 4 \cdot 23 \mathrm{pg} / \mathrm{ml})\left({ }^{*} P<0 \cdot 05\right)$.

Serum 17ß-oestradiol levels and constitutive IL-6 gene expression in the PBMC of postmenopausal women

When the relationship between the levels of $17 \beta-$ oestradiol and IL-6 gene expression in the non-stimulated PBMC was analysed, it appeared that a constitutive IL-6 gene expression was found in those postmenopausal women who had significantly lower mean serum levels of

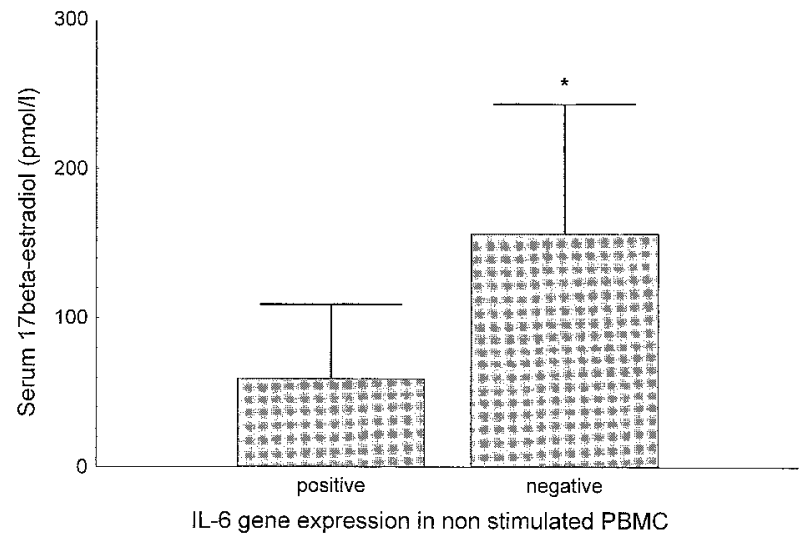

Figure 4 Serum $17 \beta$-oestradiol levels and expression of the IL- 6 gene in the non-stimulated PBMC of postmenopausal women. Postmenopausal women with IL-6 gene expression $(n=15)$ in the non-stimulated PBMC, isolated directly from venous blood, had significantly lower serum $17 \beta$-oestradiol levels compared with those who did not express the IL- 6 gene in the PBMC $(n=7)$ $(59 \cdot 05 \pm 49 \cdot 62 \mathrm{pmol} / \mathrm{l}$ vs $156 \pm 86.65 \mathrm{pmol} / \mathrm{l})\left({ }^{*} P<0 \cdot 05\right)$.

$17 \beta$-oestradiol compared with those who did not show a constitutive expression of the IL-6 gene in their PBMC $(59 \cdot 05 \pm 49 \cdot 62 \mathrm{pmol} / 1$ vs $156 \pm 86 \cdot 65 \mathrm{pmol} / 1, \quad P<0 \cdot 05)$ (Fig. 4).

In vitro effects of $17 \beta$-oestradiol on spontaneous IL-6 production by the PBMC of postmenopausal women

PMBC obtained from postmenopausal women were incubated for $24 \mathrm{~h}$ with different concentrations of
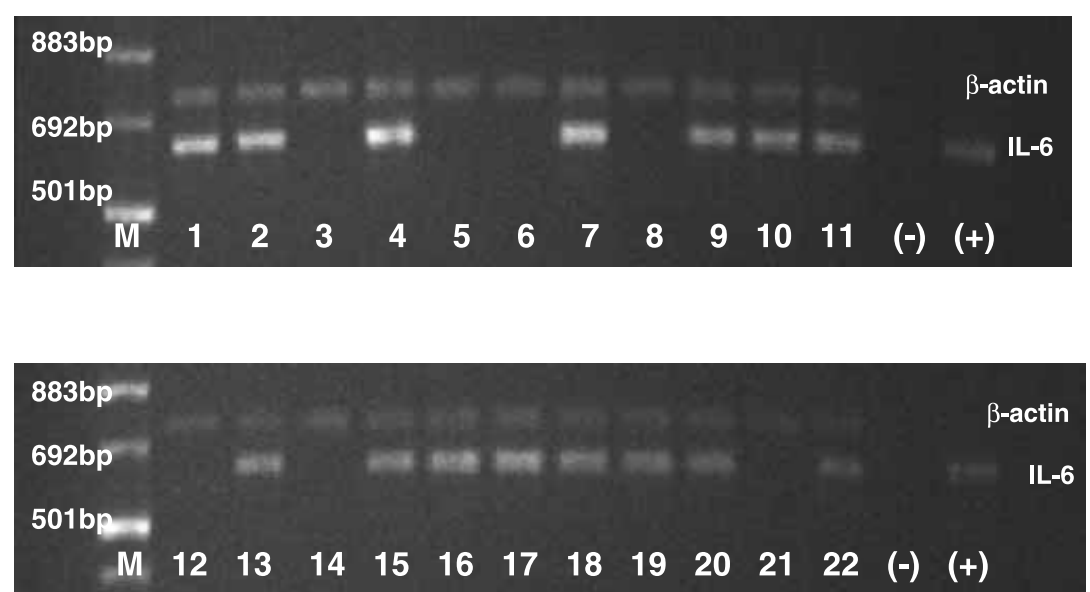

Figure 3 RT-PCR analysis of IL-6 gene expression in the non-stimulated PBMC of postmenopausal women. RNA was isolated from the non-stimulated PBMC of the 22 postmenopausal women. cDNA was then synthesized and used as a template in a 33 cycle PCR reaction employing oligonucleotide primers specific for IL- 6 and $\beta$-actin. PCR products were analysed by agarose gel electrophoresis stained with ethidium bromide and visualized under UV light. Lanes 1 to 22 correspond to the patients' numbers. $M$ is the molecular marker pUC Mix Marker 8 (MBI; Fermentas AB, Vilnius, Lithuania). (-) is the negative control and $(+)$ is the positive control. 


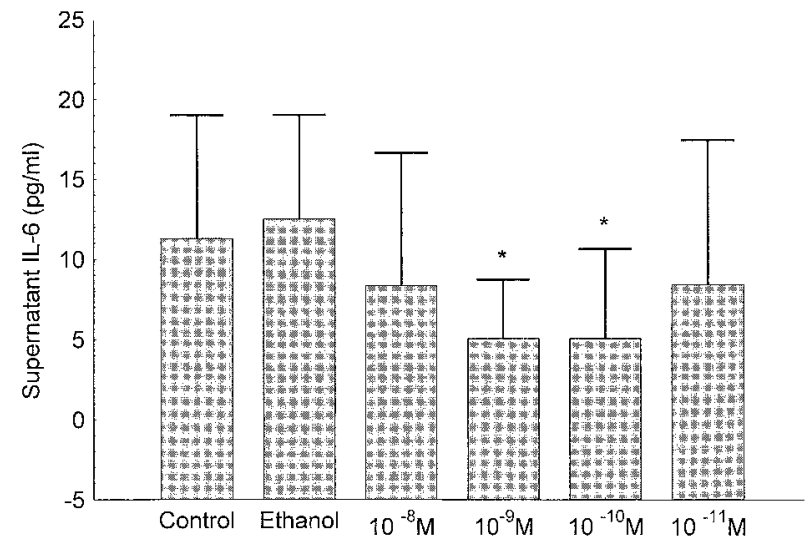

Figure 5 In vitro effects of $17 \beta$-oestradiol on the spontaneous IL-6 production by the PBMC of postmenopausal women. PBMC isolated from postmenopausal women $(n=22)$ were incubated for $24 \mathrm{~h}$ with different concentrations of $17 \beta$-oestradiol. After the incubation period, the bioactive levels of IL- 6 were measured in the supernatants using the B9 hybrydoma proliferation assay. $17 \beta$-Oestradiol at the concentrations of $10^{-9} \mathrm{M}$ and $10^{-10} \mathrm{M}$ significantly decreased the spontaneous IL-6 production into the culture supernatants by the PBMC of postmenopausal women $\left({ }^{*} P<0 \cdot 05\right)$.

$17 \beta$-oestradiol $\left(10^{-8}\right.$ to $\left.10^{-11} \mathrm{M}\right)$. After the incubation period, the culture supernatants were collected and the bioactive levels of IL-6 were measured. $17 \beta$-Oestradiol at the concentrations of $10^{-9}$ and $10^{-10} \mathrm{M}$ significantly decreased the spontaneous IL-6 production by the PBMC of postmenopausal women $(P<0 \cdot 05)$ (Fig. 5).

In vivo effects of $17 \beta$-estradiol on spontaneous IL-6 production by the PBMC of postmenopausal women

Seventeen out of twenty-two postmenopausal women who were enrolled into the study were treated with $50 \mu \mathrm{g}$ $17 \beta$-estradiol/day transdermally (Estraderm 50MX). After 6 and 12 months of the therapy, PMBC were isolated from venous blood and incubated for $24 \mathrm{~h}$ in a medium supplemented with FCS in a humidified atmosphere with 5\% $\mathrm{CO}_{2}$. After the incubation period, the levels of IL-6 were measured in the supernatants. PBMC of postmenopausal women after 12 months of oestrogen treatment released significantly smaller amounts of bioactive IL-6 into the culture media than at baseline $(11 \cdot 11 \pm 4 \cdot 44 \mathrm{pg} / \mathrm{ml}$ vs $14 \cdot 83 \pm 6 \cdot 37 \mathrm{pg} / \mathrm{ml}, P<0 \cdot 05$ ) (Fig. 6).

\section{Discussion}

The aim of this study was to clarify whether oestrogen deprivation after menopause results in an enhanced IL-6 production by the PBMC of postmenopausal women. We found that serum levels of IL-6 in the postmenopausal women were higher compared with the young eugonadal

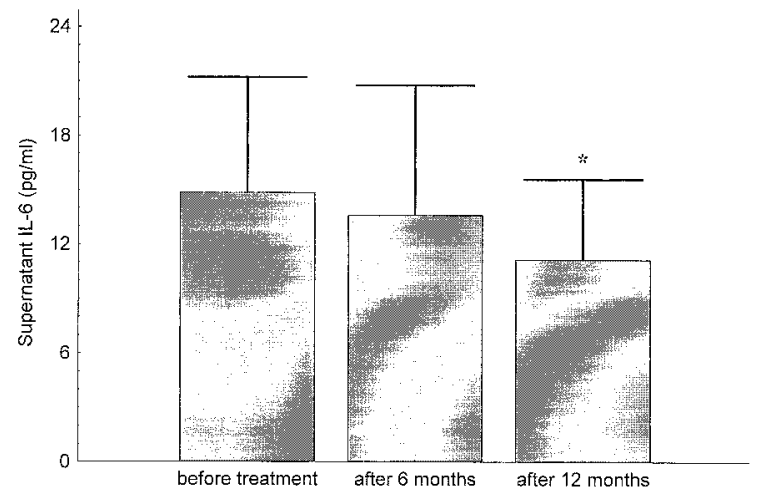

Figure 6 In vivo effects of $17 \beta$-oestradiol on the spontaneous IL-6 production by the PBMC of postmenopausal women. Seventeen out of twenty-two postmenopausal women were treated with $50 \mu \mathrm{g} 17 \beta$-oestradiol/day transdermally (Estraderm 50MX). After 6 and 12 months of treatment, PMBC were isolated from venous blood and incubated for $24 \mathrm{~h}$ in a medium supplemented with FCS in a humidified atmosphere with $5 \% \mathrm{CO}_{2}$. After the incubation period, the bioactive levels of IL- 6 were measured in the supernatants using the B9 hybrydoma proliferation assay. PBMC of postmenopausal women treated with $17 \beta$-oestradiol released significantly smaller amounts of bioactive IL- 6 into the culture media after 12 months of treatment than at baseline $\left(11 \cdot 11 \pm 4 \cdot 44 \mathrm{pg} / \mathrm{ml}\right.$ vs $14 \cdot 83 \pm 6 \cdot 37 \mathrm{pg} / \mathrm{ml}\left({ }^{*} P<0 \cdot 05\right)$.

female controls. The spontaneous IL-6 production by non-stimulated PBMC into the culture supernatants was also significantly higher in the postmenopausal women in relation to the young. We also found that, among the majority of postmenopausal women, IL-6 gene expression was present in the non-stimulated PBMC isolated directly from venous blood, which suggests the possibility of an endogenous activation of these cells in vivo. In addition, women with constitutive IL-6 gene expression in the non-stimulated PBMC had significantly lower serum $17 \beta$-oestradiol levels compared with those who did not express the IL-6 gene in the PBMC.

It has been pointed out that the enhanced IL-6 production by PBMC from postmenopausal women may not only be the consequence of the fall in oestrogen levels but may equally be determined by any of the many other factors which contribute to the aging process (Horan \& Fox 1984, Winchurch et al. 1982, Ershler et al. 1993, Fagiolo et al. 1993, Wei et al. 1993, Belmin et al. 1995, Meyer et al. 1996, Myśliwska et al. 1998). To address these issues we also studied the in vitro as well as the in vivo effects of $17 \beta$-oestradiol on the spontaneous IL- 6 production by the PBMC of postmenopausal women. Our in vitro experiments showed that $17 \beta$-oestradiol at the concentrations of $10^{-9}$ and $10^{-10} \mathrm{M}$ significantly decreased the spontaneous IL-6 production by the PBMC of postmenopausal women. The in vivo treatment with $17 \beta$-oestradiol also resulted in a significant decrease in the spontaneous IL-6 production by the PBMC of the postmenopausal women after 12 months of therapy. From these results we can 
conclude that oestrogen deprivation after menopause may contribute to the enhanced IL-6 production by the non-stimulated PBMC of the postmenopausal women.

Inappropriate expression and production of IL-6 is thought to be involved in the pathogenesis of numerous diseases, including osteoporosis (Manolagas \& Jilka 1995), CHD (Huber et al. 1999) and AD (Mrak et al. 1995). Conversely, these disorders belong to the late complications of menopause and oestrogen replacement therapy may improve them (Lindsay et al. 1984, Stampfer \& Colditz 1991, Tang et al. 1996).

Osteoporosis is among the most common causes of morbidity in older people (Chrischilles et al. 1991). IL-6 is a potent regulator of bone resorption (Ishimi et al. 1990). It is produced locally in the bone microenvironment, where it stimulates the differentiation and proliferation of haematopoietic osteoclast progenitor cells (Kurihara et al. 1991, Tamura et al. 1993). IL-6 seems to play a significant role in the pathogenesis of postmenopausal osteoporosis (Manolagas \& Jilka 1995). In rodent models, IL-6mediated stimulation of osteoclast differentiation and proliferation and its upregulation in oestrogen-depleted states is well documented (Girasole et al. 1992, Passeri et al. 1993). Bone marrow cells from women who had discontinued oestrogen replacement therapy within 1 month before marrow aspiration secreted significantly more IL-6 than bone marrow cells from either premenopausal or late postmenopausal subjects (Bismar et al. 1995). However, elevated plasma levels of IL-6 in postmenopausal women do not correlate with bone density or osteocalcin, a marker of bone turnover (Kania et al. 1995). However, epidemiological data show that serum IL-6 is a predictor of postmenopausal bone loss, and that the effect appears to be most relevant through the first postmenopausal decade (Scheidt-Nave et al. 2001).

CHD is the leading cause of death in women. It is relatively uncommon in premenopausal women but the increased incidence of the disease is seen with the loss of ovarian function (Stampfer et al. 1990). With the recognition that atherosclerosis is an inflammatory process (Ross 1999), several plasma markers of inflammation have been evaluated as potential tools for prediction of the risk of coronary events. Elevated plasma fibrinogen is now well established as an independent vascular risk factor (Cook \& Ubben 1987, Ernst \& Resch 1993). Fibrinogen is the chief determinant of plasma viscosity and plays a key role in platelet aggregation (Meade et al. 1985). Plasma C-reactive protein (CRP) has also recently been indicted as a strong cardiovascular risk factor (Ridker et al. 2000a). The possibility that CRP might, in fact, be a mediator of this risk is suggested by reports that CRP promotes the expression of tissue factor (thromboplastin) by monocytes (Cermak et al. 1993). Fibrinogen and CRP are acutephase proteins, and the most potent and broadly effective stimulant of their production by human hepatocytes appears to be IL-6 (Castell et al. 1990). Therefore, in a prospective study in apparently healthy men, elevated levels of IL-6 were associated with increased risk of future myocardial infarction (Ridker et al. 2000b). Also, Volpato et al. (2001) showed that serum IL-6 levels are helpful in identifying a subgroup of older CHD female patients with a high risk of death over a period of 3 years.

An enhanced IL-6 production also seems to play a great role in the pathogenesis of $\mathrm{AD}$ - a chronic, low-grade, self-reinforcing acute-phase inflammatory process, confined to the affected regions of the brain (Mrak et al. 1995). A pathogenic role for IL-6 specifically is suggested by reports that IL-6 can be detected in early stage 'diffuse' plaques, solely in the brains of patients with $\mathrm{AD}$ (Hüll et al. 1996). Brain-specific over-expression of IL-6 in transgenic mice also results in age-related neurodegeneration associated with learning disabilities (Heyser et al. 1997). How this process results in the amyloid deposition, neurofibrillary tangles and loss of synapses and neurones characteristic of advanced plaques is not yet clear. Ganter et al. (1991) suggested that IL-6-mediated induction of acutephase protease inhibitors (perhaps $\alpha 2$-macroglobulin) may prevent the normal proteolytic processing of the amyloid precursor protein, resulting in the formation and deposition of the insoluble $\beta$-amyloid protein that may be largely responsible for neurotoxicity. Our postmenopausal women did not have any signs of dementia or loss of cognitive functions. However, it would be reasonable to follow-up their health status until later decades of life in order to see if there is a link between an exaggerated IL- 6 production after menopause and the development of AD.

In summary, our results indicate that oestrogen deprivation after menopause may enhance IL-6 production by the PBMC of postmenopausal women. It is therefore justifiable to end the speculations about the effects of oestrogen withdrawal on IL-6 production by immune cells. Further studies are warranted to clarify if the favourable effects of HRT are mediated by the repression of IL-6 production - the cytokine which seems to be a central mediator in the pathogenesis of the late complications of menopause.

\section{Acknowledgements}

We thank Mrs Krystyna Wilczewska for excellent technical assistance. This work was supported by the grants ST12 and ST28 from the Medical University of Gdańsk.

\section{References}

Aarden LA, DeGroot ER, Schaap OL \& Lansdrop PJ 1987 Production of hybrydoma growth factor by human monocytes. European Journal of Immunology 17 1411-1416.

Belmin J, Bernard C, Corman B, Merval R, Esposito B \& Tedgui A 1995 Increased production of tumor necrosis factor and interleukin-6 by arterial wall of aged rats. American Journal of Physiology 268 H2288-H2293. 
Bismar H, Diel I, Ziegler R \& Pfeilschifter J 1995 Increased cytokine secretion by human bone marrow cells after menopause or discontinuation of estrogen replacement. Journal of Clinical Endocrinology and Metabolism 80 3351-3355.

Castell JV, Gomez-Lechon MJ, David M, Fabra R, Trullenque R \& Heinrich PC 1990 Acute-phase response of human hepatocytes: regulation of acute-phase protein synthesis by interleukin-6. Hepatology 12 1179-1186.

Cermak J, Key NS, Bach RR, Balla J, Jacob HS \& Vercellotti GM 1993 C-reactive protein induces human peripheral blood monocytes to synthesize tissue factor. Blood 82 513-520.

Chaudhary LR, Spelsbert TC \& Riggs BL 1992 Production of various cytokines by normal human osteoblast-like cells in response to interleukin-1 beta and tumor necrosis factor alpha: lack of regulation by 17 beta estradiol. Endocrinology 130 2528-2534.

Chrischilles EA, Butler CD, Davis CS \& Wallace RB 1991 A model of lifetime osteoporosis impact. Archives of Internal Medicine $\mathbf{1 5 1}$ 2026-2032.

Cook NS \& Ubben D 1987 Fibrinogen as a major risk factor in cardiovascular disease. Trends in Pharmacological Sciences 11 444-451.

Ernst E \& Resch KL 1993 Fibrinogen and viscosity as risk factors for subsequent cardiovascular events in stroke survivors. Annals of Internal Medicine 118 956-963.

Ershler WB, Sun WH, Binkley N, Gravenstein S, Volk MJ, Kamoske G, Klopp RG, Roecker EB, Daynes RA \& Weindruch R 1993 Interleukin-6 and aging: Blood levels and mononuclear cell production increase with advancing age and in vitro production is modifiable by dietary restriction. Lymphokine and Cytokine Research 12 225-230.

Fagiolo U, Cossarizza A, Scala E, Fanales-Belasio E, Ortolani C, Cozzi E, Monti D, Franceschi C \& Paganelli R 1993 Increased cytokine production in mononuclear cells of healthy elderly people. European Journal of Immunology 23 2375-2378.

Ganter U, Strauss S, Jonas U, Weidemann A, Beyreuther K, Volk B, Berger M \& Bauer J 1991 Alpha 2-macroglobulin synthesis in interleukin-6-stimulated human neuronal (SH-SY5Y neuroblastoma) cells. Potential significance for the processing of Alzheimer beta-amyloid precursor protein. FEBS Letters 282 127-131.

Girasole G, Jilka RL, Passeri G, Boswell S, Boder G \& Williams DC 199217 Beta-estradiol inhibits interleukin-6 production by bone marrow-derived stromal cells and osteoblasts in vitro: a potential mechanism for the antiosteoporotic effect of estrogens. Journal of Clinical Investigation 89 883-891.

Heyser CJ, Masliah E, Samimi A, Campbell IL \& Gold LH 1997 Progressive decline in avoidance learning paralleled by inflammatory neurodegeneration in transgenic mice expressing interleukin 6 in the brain. PNAS 94 1500-1505.

Horan MA \& Fox RA 1984 Ageing and immune response: a unifying hypothesis. Mechanisms of Ageing and Development 26 65-181.

Huber SA, Sakkinen P, Conze D, Hardin N \& Tracy R 1999 Interleukin-6 exacerbates early atherosclerosis in mice. Arteriosclerosis, Thrombosis, and Vascular Biology 19 2364-2367.

Hüll M, Berger M, Volk B \& Bauer J 1996 Occurrence of interleukin-6 in cortical plaques of Alzheimer's disease patients may precede transformation of diffuse into neuritic plaques. Annals of the New York Academy of Science 777 205-212.

Ishimi Y, Miyaura C, Jin CH, Akatsu T, Abe E, Nakamura Y, Yamaguchi A, Yoshiki S, Matsuda T \& Hirano T 1990 IL-6 is produced by osteoblasts and induces bone resorption. Journal of Immunology 145 3297-3303.

Kania DM, Binkley N, Checovich M, Havighurst T, Schilling M \& Ershler WB 1995 Elevated plasma levels of interleukin-6 in postmenopausal women do not correlate with bone density. Journal of the American Geriatrics Society 43 236-239.

Kassem M, Harris SA, Spelsberg TC \& Riggs BL 1996a Estrogen inhibits interleukin-6 production and gene expression in a human osteoblastic cell line with high levels of estrogen receptors. Journal of Bone and Mineral Research 11 193-199.
Kassem M, Khosla S, Spelsberg TC \& Riggs BL 1996 Cytokine production in the bone marrow microenvironment: failure to demonstrate estrogen regulation in early postmenopausal women. Journal of Clinical Endocrinology and Metabolism $\mathbf{8 1}$ 513-518.

Kurihara N, Civin C \& Roodman GD 1991 Osteotropic factor responsiveness of highly purified populations of early and late precursors for human multinucleated cells expressing the osteoclast phenotype. Journal of Bone and Mineral Research 6 257-261.

Lindsay R, Hart DM \& Clark DM 1984 The minimum effective dose of estrogen for prevention of postmenopausal bone loss. Obstetrics and Gynecology 63 759-763.

McKane WR, Khosla S, Peterson JM, Egan K \& Riggs BL 1994 Circulating levels of cytokine that modulate bone resorption: effects of age and menopause in women. Journal of Bone and Mineral Research 9 1313-1318.

Manolagas SC \& Jilka RL 1995 Bone marrow, cytokines, and bone remodeling. Emerging insights into the pathophysiology of osteoporosis. New England Journal of Medicine 332 305-311.

Meade TW, Vickers MV, Thompson SG \& Seghatchian MJ 1985 The effect of physiological levels of fibrinogen on platelet aggregation. Thrombosis Research 38 527-534.

Meyer KC, Ershler W, Rosenthal NS, Lu XG \& Peterson K 1996 Immune dysregulation in the aging human lung. American Journal of Respiratory and Critical Care Medicine 153 1072-1079.

Mrak RE, Sheng JG \& Griffin WST 1995 Glial cytokines in Alzheimer's disease. Human Pathology 26 816-823.

Myśliwska J, Bryl E, Zorena K, Foerster J \& Myśliwski A 1998 Increase of interleukin-6 and decrease of interleukin-2 production during the ageing process are influenced by the health status. Mechanisms of Ageing and Development 100 313-328.

Papanicolaou DA \& Vgontzas AN 2000 Interleukin-6: the endocrine cytokine. Journal of Clinical Endocrinology and Metabolism $\mathbf{8 5}$ 1331-1332.

Passeri G, Girasole G, Jilka RL \& Manolagas SC 1993 Increased interleukin- 6 production by murine bone marrow and bone cells after estrogen withdrawal. Endocrinology 133 822-828.

Passeri G, Girasole G, Manolagas SC \& Jilka RL 1994 Endogenous production of tumor necrosis factor by primary cultures of murine calvarial cells: influence on IL-6 production and osteoclast development. Bone and Mineral 24 109-126.

Rickard D, Russell G \& Gowen M 1992 Oestradiol inhibits the release of tumor necrosis factor but not interleukin-6 from adult human osteoblasts in vitro. Osteoporosis International 2 94-102.

Ridker PM, Hennekens CH, Buring JE \& Rifai N 2000a C-reactive protein and other markers of inflammation in the prediction of cardiovascular disease in women. New England Journal of Medicine 342 836-843.

Ridker PM, Rifai N, Stampfer MJ \& Hennekens CH 2000 b Plasma concentration of interleukin-6 and the risk of future myocardial infarction among apparently healthy men. Circulation 101 1767-1772.

Rifas L, Kenney JS, Marcelli M, Pacifici R, Cheng SL, Dawson LL \& Avioli LV 1995 Production of interleukin-6 in human osteoblasts and human bone marrow stromal cells: evidence that induction by interleukin-1 and tumor necrosis factor-alpha is not regulated by ovarian steroids. Endocrinology 136 4056-4067.

Ross R 1999 Atherosclerosis - an inflammatory disease. New England Journal of Medicine 340 115-126.

Scheidt-Nave C, Bismar H, Leidig-Bruckner G, Woitge H, Seibel MJ, Ziegler R \& Pfeilschifter J 2001 Serum interleukin 6 is a major predictor of bone loss in women specific to the first decade past menopause. Journal of Clinical Endocrinology and Metabolism 86 2032-2042.

Stampfer MJ \& Colditz GA 1991 Estrogen replacement therapy and coronary heart disease: a qualitive assessment of the epidemiologic evidence. Preventive Medicine 20 47-63. 
Stampfer MJ, Colditz GA \& Willett WC 1990 Menopause and heart disease. A review. Annals of the New York Academy of Science 592 193-203.

Straub RH, Hense HW, Andus T, Scholmerich J, Riegger GA \& Schunkert H 2000 Hormone replacement therapy and interrelation between serum interleukin- 6 and body mass index in

postmenopausal women: a population based study. Journal of Clinical Endocrinology and Metabolism 85 1340-1344.

Tamura T, Udagawa N, Takahashi N, Miyaura C, Tanaka S, Yamada Y, Koishihara Y, Ohsugi Y, Kumaki K \& Taga T 1993 Soluble interleukin-6 receptor triggers osteoclast formation by interleukin-6. PNAS 90 11924-11928.

Tang MX, Jacobs D, Stern Y, Marder K, Schofield P, Gurland B, Andrews H \& Mayeux R 1996 Effect of oestrogen during menopause on risk and age at onset of Alzheimer's disease. Lancet 348 429-432.
Volpato S, Guralnik JM, Ferrucci L, Balfour J, Chaves P, Fried LP \& Harris TB 2001 Cardiovascular disease, interleukin-6, and risk of mortality in older women: the women's health and aging study. Circulation 103 947-953.

Wei J, Xu H, Davies JL \& Hemmings GP 1993 Increase of plasma IL-6 concentration with age in healthy subjects. Life Sciences $\mathbf{5 1}$ 1953-1956.

Winchurch RA, Birmingham W, Hilberg C \& Munster A 1982 Effect of endotoxin on immunity in aging mice. Cell Immunology 67 384-389.

Received in final form 30 August 2001 Accepted 9 October 2001 